\title{
Typology, Structural Characterization and Sustainability of Integrated Broiler Farming System in Epirus, Greece
}

\author{
Vassilios Dotas ${ }^{1, *} \mathbb{0}$, Dimitrios Gourdouvelis ${ }^{1}$, Lampros Hatzizisis ${ }^{2}$, Ioannis Kaimakamis ${ }^{3}$, \\ Ioannis Mitsopoulos ${ }^{4}$ and George Symeon ${ }^{5}$ (D) \\ 1 Department of Animal Production, Faculty of Agriculture, Aristotle University of Thessaloniki, \\ 54124 Thessaloniki, Greece; dgourdou@agro.auth.gr \\ 2 Faculty of Agriculture, University of Ioannina, 47100 Arta, Greece; lamprosxatz@yahoo.gr \\ 3 Department of Animal Science, School of Agricultural Sciences, University of Thessaly, 41334 Larissa, Greece; \\ ikaimaka@auth.gr \\ 4 Department of Agriculture, School of Geosciences, International Hellenic University, 57400 Sindos, Greece; \\ gmitsop@ihu.gr \\ 5 Research Institute of Animal Science, Hellenic Agricultural Organization Demeter, 58100 Giannitsa, Greece; \\ gsymewn@yahoo.gr \\ * Correspondence: vdotas@agro.auth.gr; Tel.: +30-2310991735
}

check for

updates

Citation: Dotas, V.; Gourdouvelis, D.; Hatzizisis, L.; Kaimakamis, I.;

Mitsopoulos, I.; Symeon, G. Typology,

Structural Characterization and

Sustainability of Integrated Broiler Farming System in Epirus, Greece.

Sustainability 2021, 13, 13084.

https: / / doi.org/10.3390/

su132313084

Academic Editor: Giuseppe Todde

Received: 8 November 2021

Accepted: 23 November 2021

Published: 26 November 2021

Publisher's Note: MDPI stays neutral with regard to jurisdictional claims in published maps and institutional affiliations.

Copyright: (c) 2021 by the authors. Licensee MDPI, Basel, Switzerland. This article is an open access article distributed under the terms and conditions of the Creative Commons Attribution (CC BY) license (https:/ / creativecommons.org/licenses/by/ $4.0 /)$.

\begin{abstract}
The aim of this study was the detailed characterization of the existing zootechnical and financial management applied in broiler poultry farms in the Region of Epirus, Greece. The current situation was captured through the formation of a typology on the structural characterization of broiler farming system. The variables were recorded based on data from a stratified random sample according to Neyman's methodology of 110 poultry farms. In the typology, hierarchical cluster analysis was applied to identify differences between farms and to support most of this differentiation. Chebyshev distance was used to maximize the effect of the cluster elements distance, as well as Ward's clustering method, which aims to achieve greater homogeneity within the clusters. Bonferroni multiple comparison tests were used to evaluate the differences. Four clusters of different farm types were identified from the hierarchical cluster analysis. In conclusion, the production system of broiler farms in Epirus is intensive, especially in large farms that have made significant investments in fixed capital and implement successful management. However, the poultry sector in Epirus has further margin for improvement in both its productivity and profitability.
\end{abstract}

Keywords: broiler farms; farming system; hierarchical cluster analysis; sustainable development

\section{Introduction}

Over the past decades, the broiler industry in Greece has made tremendous progress to meet the growing demand for inexpensive and safe supply of high-quality meat. This development was combined with structural changes in the sector, characterized by the modernization of farming facilities, the intensification of the farming system and the concentration of poultry farms.

One such area with a high concentration of poultry activity and mainly broiler farming in Greece is the Region of Epirus (45\% of the total national broiler production). The Region of Epirus is one of the 13 Regions of Greece. It occupies an area of $9203 \mathrm{~km}^{2}$, and its population amounts to 336,856 inhabitants. The total generated GDP amounts to EUR 4499 million, which is $2.2 \%$ of the total GDP of Greece. Agriculture and livestock have a turnover of EUR 235.4 million and the food industry EUR 353.9 million [1]. The developed farming system of broiler production in the Region of Epirus is considered intensive, industrial, and large-scale according to the classification scale of Camargo-Barros et al. [2]. The Greek poultry industry is structured around a few large vertically integrated companies (i.e., "Pindos Poultry Co-operative", "Arta Poultry Co-operative" and "Nitsiakos S.A." 
in the Region of Epirus) operating throughout the whole supply chain, from feed production and preparation to breeding, raising, and delivering the end products to retailers [3].

Large initial and operating costs, as well as economies of scale and more efficient capital investments, lead broiler farmers to establish larger scale commercial farms (i.e., flock sizes of more than 10,000 and up to 100,000 birds) and to participate into large enterprises [4,5]. The facilities are well equipped and relatively mechanized, including both semi-automatic and automatic equipment. The available automated systems include supply systems, water supply with nipples and central control for temperature/humidity, ventilation and lighting. Some systems have more extensive automation, including remote digital monitoring and computer controls [6].

Regarding Greece, the self-sufficiency rate in poultry meat reaches approximately $75 \%$, and the corresponding imports in the year 2018 amounted to 82,000 tons [7]. During the same period, the corresponding exports of poultry meat to EU countries amounted to 22,000 tons of carcass weight. Covering national self-sufficiency in poultry meat makes it imperative to intensify the production system and increase productivity, reduce production costs, improve specific production indicators, and use innovative and sustainable practices with European legislation [8].

An effective tool that highlights how the particular structural characteristics of farms affect the efficient use of their own resources (land, labor and capital), but also the choice of actions and investments that can be made for their utilization, is the typology of farms [9]. The main objective of research focusing on the construction of a farm typology is to identify the farming system in the case study region [10]. A farm typology allows an overall assessment of farming activities not only in terms of farm structural characteristics (i.e., farm size, managerial ownership and farm intensity), but also in terms of farm economics [11]. Determining the types of poultry farms can be achieved with cluster analysis (C.A.) which is one of the most basic data analysis tasks. The aim of C.A. is the division of a total sample into clusters formed based on the similarity of their members [12]. Cluster analysis has been used in many cases to study the typology and productivity in broiler farming worldwide [13-18]. Corresponding studies, i.e., application of farm typology, regarding broiler farms in the direction of structural characterization, economic viability and future sustainability have not been conducted in Greece.

One of the most important concerns of the European Union is the achievement of sustainable development of human activities, such as the intensive broiler production [19]. Moreover, farmers evaluate their production practices mainly on the basis of economic efficiency, which generally requires large amounts of inputs, paying little attention to environmental pollution and future sustainability [20]. According to Vaarst et al. [21] the concept of 'sustainability' of a single agricultural sector is multi-dimensional, encompassing economic (production of valuable and cheap food), environmental (pollution and use of antibiotics), social (work conditions and animal welfare) and institutional (food chain governance) aspects. The economic impact of EU legislation on environmental protection, food safety and animal welfare and its implementation in the poultry sector has led to an increase in production costs estimated at 0.05 euros per kilogram $(\mathrm{kg})$ of chicken live weight on average [22,23].

Poultry production has been found to be relatively environmentally friendly compared to the production of other terrestrial animals [24] because it has the best conversion rate of feed into human food and the smallest environmental footprint in terms of energy and water use per kilogram of meat produced [25]. As the production and transport of feeds contribute about $70 \%$ to the global warming potential of poultry systems, while manure management contributes to their eutrophication and acidification potential (nutrient waste) by about 40 and $60 \%$, respectively [24-26], an important measure to reduce the impact of poultry activities is to improve feed efficiency by implementing better management practices or by using alternative feed additives (e.g., enzymes) and selected genetic material $[19,21,26-28]$. 
All of the above indicate that when using the C.A. to build a typology for such an intensified sector as broiler farming, all those economic and managerial indicators that contribute to the sustainable development and future viability of this sector should be taken into account. One of the most crucial factors affecting the profitability and economic viability of broiler farms is the feed conversion ratio (FCR) $[29,30]$. This is because the cost of feeds in broiler farming constitutes the largest percentage of variable costs, about $70 \%$ [31-33], and has an impact on the productivity and profitability of each farm, especially when economies of scale increase. It follows that the size of a farm and its financial viability are strongly related [34]. In terms of improving environmental sustainability, FCR is again the key factor both in reducing the environmental footprint of feedstuffs and in manure management due to reduced nutrient losses $[24,27,28,35]$. In addition, the technical and economic efficiency of broiler farms, according to Marcu et al. [36], is greatly influenced by the FCR and other productivity indexes included in the European Production Efficiency Factor (EPEF), which has been used by many researchers [37-41] to compare the results of broilers from different flocks and different regions. In the current study, this index (EPEF) will be used to confirm the results of the cluster analysis, by comparing the technical efficiency of the created clusters.

In summary, the aim of this study is the detailed characterization of the existing zootechnical, and financial management applied in broiler poultry farms in the Region of Epirus. The current situation was reflected in the formation of a typology on the structural characterization of the production of broiler farms. The analysis and interpretation of the common characteristics of the created clusters of farms will reflect the existing liabilities of the farming system but will also identify the key points that will be the lever of support for achieving social and economic development and sustainability of the sector.

\section{Materials and Methods}

\subsection{Study Area}

In the present study, the administrative Region of Epirus has been defined as the research area. This region includes a total of 4 Regional Units (R.U.); the R.U. of Ioannina and Arta, which have a large number of broiler farms, the R.U. of Preveza that participated in the sampling with a small number of respective farms and the R.U. of Thesprotia, where there were no industrial-sized broiler farms.

The capacity of the farms ranges from 5001 broilers to over 75,000 chickens. Therefore, the minimum size per production cycle carried out by each farm participating in the sample is 5001 chickens. The main reason that farms with less than 5001 chickens were not included in the original sample was that such small-scale farms do not participate in the existing vertical and integrated business or cooperative schemes operating in the Region.

The farms that formed the original sample cooperate either with private companies or are members of cooperatives that have systems for processing, slicing and marketing of chickens and their products, as well as modern slaughterhouses of high productivity with freezing, slicing, cooking and packing infrastructure. They also have broiler breeders' farms that supply eggs to privately owned hatcheries for the production of day-one chicks, as well as privately owned feedstuff mills.

The sampling framework was designed based on the statistical data of EL.STAT. [1]. According to the data obtained, the distribution of broiler farms in the Region of Epirus is presented in Table 1.

\subsection{Data Collection and Sample Determination}

The structured questionnaire method was used to collect the survey data, in a selected representative and proportional sample of statistically sufficient size. The survey, conducted in the year 2019, required the use of a questionnaire with a detailed record of the technical and economic data describing the structure of each farm. These are technical and economic characteristics related to both inputs (factors of production used) and outputs (final products) related to the broilers' farming. 
Table 1. Distribution of broiler farms in the Region of Epirus.

\begin{tabular}{ccc}
\hline Regional Unit & Number of Farms & $\begin{array}{c}\text { Total Production } \\
\text { (Number of Chickens/Year) }\end{array}$ \\
\hline Ioannina & 767 & $26,475,000$ \\
Arta & 214 & $15,000,000$ \\
Preveza & 23 & 700,000 \\
Thesprotia & - & - \\
Total & 1004 & $42,175,000$ \\
\hline
\end{tabular}

The initial number of 1004 farms was divided into 4 size categories according to the number of broilers reared per year, regardless of the annual placements. According to Unay-Gailhard et al. [10] and FAO [42], farm size (physical and economic) is one of the most important categorization variables in typologies because it determines significant differences between farms. The first category, M1, included farm sizes from 5001-25,000 chickens per production cycle, the second, M2, from 25,001-50,000, the third, M3, from 50,001-75,000 and the last, M4, more than 75,001 chickens.

The sampling method followed was Neyman's stratified sampling method $[43,44]$. The distribution of the sample into stratums is given by the following equation [45]:

$$
n_{h}=n \cdot \frac{N_{h} S_{h}}{\sum_{h=1}^{H} N_{h} S_{h}}
$$

where:

$n=$ sample size

$n_{h}=$ sample size of stratum $h$

$N$ = size of total (initial) sample

$N_{h}=$ size of total sample concerning stratum $h$

$S_{h}=$ the standard deviation of the variable in each stratum

$$
S_{h}=\sqrt{\frac{1}{N_{h}-1} \sum_{i=1}^{N_{h}}\left(y_{i}-\bar{y}_{i}\right)^{2}}
$$

$y_{i}=$ the stratification-related variable.

The final sample included 110 farms and constitutes $9.13 \%$ of the total broiler farms in the study area. The number of broilers per year in the final sample amounted to $3,241,480$ chickens, which is $7.7 \%$ of the total population of the sampling frame. There is a sufficient sample, and therefore the estimates are representative and can be generalized. According to the above stratification methodology, the sample collected from all 3 Regional Units and the 4 size categories is presented in Table 2.

\begin{tabular}{|c|c|c|c|c|c|}
\hline \multirow{2}{*}{ Regional Unit } & \multicolumn{4}{|c|}{ Size Categories } & \multirow{2}{*}{ Total } \\
\hline & M1 & M2 & M3 & M4 & \\
\hline Arta & 12 & 10 & 2 & 1 & 25 \\
\hline Ioannina & 49 & 26 & 4 & 2 & 81 \\
\hline Preveza & 2 & 1 & 1 & - & 4 \\
\hline Total & 63 & 37 & 7 & 3 & 110 \\
\hline
\end{tabular}

Table 2. Distribution of broiler farms in the 3 R.U. of Epirus, per size categories.

The random selection of farms in the final sample was done according to the range of each selection, using an initially random start number of each selection [46]. The selection range from which the successively selected farms were obtained through the 2-way stratification was calculated as the quotient in each $\mathrm{Nh}$ stratum to the number of sample members 
in each $n_{h}$ stratum [47]. The calculation was performed using the OpenEpi Open-Source Calculator, Version 3.

\subsection{Data Processing}

The primary data were collected through questionnaires recording the main characteristics of each farm that concerned (a) the applied management practices and (b) the financial data. The data were encoded and integrated into tables, coded sheets of MS-Excel, in order to create a matrix-database for further statistical analysis with SPSS version 25 and $\mathrm{R}$ software by adding (adds-on) the Benchmarking Package in the MacOS High Sierra operating system.

Multivariate statistical analysis was used to process and interpret the data by creating separate groups of farms that apply a separate rearing model in order to identify differences between farms and to support most characteristics of this differentiation [48].

\subsection{Hierarchical Cluster Analysis}

The multivariate statistical technique used in the present study to determine the relationship of various quantitative parameter, was the hierarchical cluster analysis. The cluster analysis aims to create homogeneous (internally) groups of production systems, in terms of their technical and economic characteristics (variables), which differ significantly from each other. Groups are called classes or clusters. The analysis also tries to determine the number and composition of the groups. Cluster analysis is an exploratory method, and the variables used can be both quantitative and qualitative, only the latter require the use of specialized techniques for their integration and separation of clusters [49].

The steps followed for the cluster analysis of the sample of 110 broiler farms are described in detail by Hair et al. [50] and Everitt et al. [51]. Initially, the items to be grouped were selected (110 farms). The following variables were then selected to fulfill the objectives of the research:

- Number of production cycles per year;

- Feed conversion ratio ( $\mathrm{kg}$ of total feed $/ \mathrm{kg}$ of final body weight);

- Average days of a production cycle-length;

- Total feed consumption ( $\mathrm{kg} /$ year);

- Mortality (\%): the index was obtained by subtracting from the number of day-old chicks placed for fattening the final output related to the total number of chickens taken to the slaughterhouse;

- Gross farm profit (euros- $€$ ).

To address the missing values for the study, the missing data were replaced by applying the mean-based method. That is, the mean value of each group was calculated, and each missing variable received the mean value of the group to which it belongs.

One way to determine the degree or extent of similarity of two observations in the data is their distance. The Chebychev distance used in the study to classify farms maximizes the effect of the data distance and is expressed by the equation:

$$
d_{i j}=\max _{i}\left|X_{i j}-X_{i k}\right|
$$

The clustering of the farms was performed using the Ward's linkage method. The analysis was based on the estimation of the variance of the observations with the ultimate goal of estimating the distances between the clusters. Essentially, with the application of the method, the minimization of the variability between the two examined clusters that are formed in each successive stage of the hierarchical analysis was achieved.

A diagrammatic representation of a hierarchical classification method is the dendrogram on the basis of which the number of groups was determined [49]. In order to evaluate the a posteriori differences, multiple comparison tests were used through the Bonferroni test which follows the criterion of the least significant difference. 
Summary cluster analysis is the organization of a collection of data or variables into classes based on a measure of similarity, in which special attention must be paid to the selection of variables that enter the analysis process [50,51].

\subsection{European Production Efficiency Factor}

To interpret the final result, the values of the variables in each group must be studied to assess whether the clusters actually exist or are simply the result of an algorithm. A useful evaluation tool that is directly related to the selected cluster classification variables is the European Production Efficiency Factor (EPEF) $[36,39]$ given by the equation:

$$
\frac{(100-\text { mortality }) \% \times \text { final body weight }(\mathrm{kg})}{\mathrm{FCR} \times \text { slaughter age of chicks }(\text { days })} \times 100=\mathrm{EPEF}
$$

\section{Results}

\subsection{Hierarchical Cluster Analysis}

The result of classification by applying the cluster analysis in the final sample of 110 broiler farms in the Region Epirus was the creation of the dendrogram (Figure 1) from which four (4) clusters of farms emerged. The distribution of farms by cluster and Regional Unit is given in Table 3.

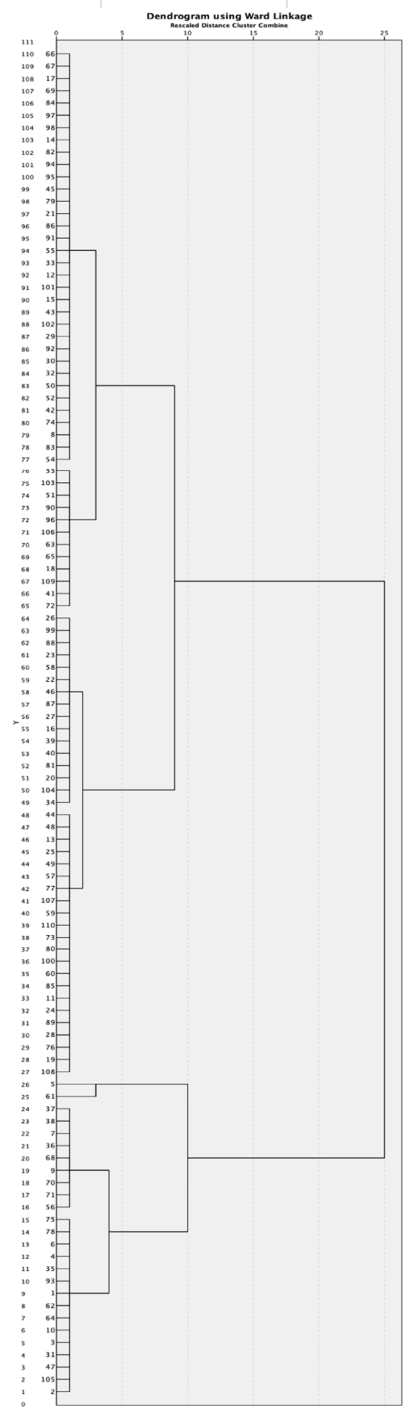

Figure 1. Classification dendrogram of 110 farms with Ward linkage technique and Chebychev similarity distance. 
Table 3. Farm types per Regional Unit.

\begin{tabular}{cccccc}
\hline \multirow{2}{*}{ Cluster } & \multicolumn{3}{c}{ Regional Unit } & \multirow{2}{*}{ Total } & $\%$ \\
\cline { 2 - 4 } & Arta & Ioannina & Preveza & & 46 \\
C1 & 11 & 35 & 0 & 38 & 41.8 \\
C2 & 8 & 30 & 0 & 2 & 1.8 \\
C3 & 1 & 1 & 0 & 24 & 21.8 \\
C4 & 5 & 15 & 4 & 110 & 100 \\
Total & 25 & 81 & 4 & & \\
\hline
\end{tabular}

The above table shows that the percentage of farms included in the 1st cluster amounts to $41.8 \%$ while the lowest frequency is shown by the 3rd cluster which includes only 2 farms. The 4th cluster includes farms with activity in all three Regional Units, with the Regional Unit of Ioannina dominating in number of farms and the other two being numerically equivalent.

\subsection{Characteristics and Interpretation of Clusters-Structural Characterization}

The formation of farm types was based on the aforementioned variables. Table 4 contains the averages by type of farm of the variables included in the analysis.

Table 4. Variable analysis of generated clusters.

\begin{tabular}{|c|c|c|c|c|c|c|c|}
\hline Variable & $\begin{array}{l}\text { Mean } \\
\text { Value }\end{array}$ & $\mathrm{C} 1$ & $\mathrm{C} 2$ & $\mathrm{C} 3$ & $\mathrm{C} 4$ & $p$ & SD \\
\hline Number of farms $(n)$ & 110 & 46 & 38 & 2 & 24 & & \\
\hline Production cycles/year/farm & 5.07 & $5.22^{b}$ & $4.58^{\mathrm{a}}$ & $6.00^{c}$ & $5.50^{\mathrm{b}}$ & $<0.001$ & 0.93 \\
\hline Feed conversion ratio & 1.81 & $1.77^{\mathrm{a}}$ & $1.86^{\mathrm{a}}$ & $2.24^{b}$ & $1.78^{\mathrm{a}}$ & 0.004 & 0.21 \\
\hline Annual rest period (days) & 81.25 & 78.24 & 85.18 & 79.00 & 80.96 & 0.618 & 23.69 \\
\hline Consumed feed $(\mathrm{tn})$ & 673.42 & $565.42^{b}$ & $271.25^{a}$ & $4156.25^{\mathrm{d}}$ & $1226.97^{c}$ & $<0.001$ & 107.75 \\
\hline Mortality (\%) & 2.91 & $3.05^{c}$ & $2.98^{b c}$ & $1.56^{\mathrm{a}}$ & $2.65^{b}$ & 0.046 & 0.35 \\
\hline Gross profit $(€)$ & 27,979 & $27,546^{\mathrm{c}}$ & $11,798^{\mathrm{b}}$ & $-202,419^{a}$ & $73,628^{d}$ & $<0.001$ & 56,942 \\
\hline $\begin{array}{c}\text { Farm size } \\
\text { (broilers/production cycle) }\end{array}$ & 29,468 & $26,847^{b}$ & $14,118^{\mathrm{a}}$ & $127,000^{\mathrm{d}}$ & $50,666^{c}$ & $<0.001$ & 20,288 \\
\hline Total number of broilers/year & 152,049 & $134,736^{\mathrm{b}}$ & $62,329^{a}$ & $752,000^{d}$ & $277,923^{c}$ & $<0.001$ & 120,700 \\
\hline $\begin{array}{c}\text { Total live weight of } \\
\text { broilers/year (tn/year) }\end{array}$ & 372.11 & $323.47^{b}$ & $147.76^{\mathrm{a}}$ & $1846.95^{\mathrm{d}}$ & $697.68^{c}$ & $<0.001$ & 304.16 \\
\hline $\begin{array}{l}\text { Average days of a production } \\
\text { cycle-length }\end{array}$ & 45.26 & 45.17 & 44.94 & 42.50 & 46.20 & 0.349 & 3.50 \\
\hline Average slaughter weight $(\mathrm{kg})$ & 2.49 & 2.48 & 2.45 & 2.48 & 2.58 & 0.107 & 0.20 \\
\hline $\begin{array}{l}\text { Average selling price/ } \\
\mathrm{kg} \text { of live weight }(€)\end{array}$ & 1.11 & 1.11 & 1.09 & 1.12 & 1.12 & 0.137 & 0.02 \\
\hline Total production days/year & 229.87 & $235.97^{b}$ & $205.79^{a}$ & $255.00^{c}$ & $254.25^{c}$ & $<0.001$ & 45.73 \\
\hline Land (ha) & 1.09 & $1.01^{\mathrm{b}}$ & $0.73^{\mathrm{a}}$ & $3.00^{\mathrm{d}}$ & $1.64^{\mathrm{c}}$ & $<0.001$ & 0.92 \\
\hline Total Fixed Capital $(€)$ & 37,187 & $32,289^{b}$ & $13,981^{a}$ & $170,268^{\mathrm{d}}$ & $72,226^{c}$ & $<0.001$ & 30,500 \\
\hline Average Gross Revenue $(€)$ & 413,953 & 357,999 b & $161,779^{a}$ & $2,056,270^{d}$ & $783,612^{c}$ & $<0.001$ & 340,681 \\
\hline Average Net Profit $(€)$ & $-16,678$ & $-12,516^{b}$ & $-9743^{c}$ & $-366,669^{\text {a }}$ & $-6469^{d}$ & $<0.001$ & 6411 \\
\hline Average Farm Income $(€)$ & 20,093 & $19,928^{c}$ & $7357^{b}$ & $-217,853^{a}$ & $60,406^{\mathrm{d}}$ & $<0.001$ & 55,583 \\
\hline $\begin{array}{c}\text { Average Return on Capital } \\
\qquad(\%)\end{array}$ & 18.90 & $-4.02^{b}$ & $48.7^{\mathrm{d}}$ & $-20.5^{a}$ & $12.4^{\mathrm{c}}$ & 0.018 & 10.6 \\
\hline $\begin{array}{l}\text { Average production cost } \\
(€ / \mathrm{kg} \text { of live weight })\end{array}$ & 0.82 & $0.82^{\mathrm{a}}$ & $0.83^{\mathrm{a}}$ & $0.94^{b}$ & $0.81^{\mathrm{a}}$ & 0.014 & 0.12 \\
\hline
\end{tabular}

a,b,c,d Values with no common superscript in the same row are statistically different, at a significance level of $p \leq 0.05$, according to the results of the Bonferroni test. 
The profile of each cluster was further investigated based on a broader framework of variables derived from field research based on the prevailing typology (4 clusters). In order to achieve optimal comparability and consequently an increased degree of interpretation of the results, the following ratio was used as a reference base:

$$
4 \text { LU (Livestock Units) }=1000 \text { broilers, }
$$

Therefore, the quantities of the variables listed in Table 5 are expressed per 1000 reared chickens.

Table 5. Basic financial results per 4 LU (1000 broilers).

\begin{tabular}{cccccc}
\hline Variable & Mean Value & C1 & C2 & C3 & C4 \\
\hline Number of farms $(n)$ & 110 & 46 & 38 & 2 & 24 \\
Farm size (number of broilers) & 29.47 & 26.85 & 14.12 & 127.00 & 50.67 \\
Total number of broilers/year & 152.05 & 134.74 & 62.33 & 752.00 & 277.92 \\
Total Fixed Capital $(€)$ & 244.65 & 239.65 & 224.32 & 226.42 & 260.00 \\
Average Gross Revenue $(€)$ & 2722.48 & 2656.97 & 2595.54 & 2734.40 & 2819.56 \\
Average Net Profit $(€)$ & -109.69 & -92.90 & -156.32 & -487.59 & -23.28 \\
Average Farm Income $(€)$ & 132.15 & 147.90 & 118.04 & -289.70 & 217.35 \\
\hline
\end{tabular}

Cluster 1 (C1). Medium-size farms, with very good feed conversion rate $(n=46)$.

This cluster includes the largest percentage of farms in the sample. As noted, the capacity of $\mathrm{C} 1$ cluster farms amounts, on average, to 26,847 broilers (107.39 LU). In farms of this cluster, 5.22 production cycles are carried out per year. The characteristic feature of these farms is the achievement of the best FCR (1.77). However, they have the highest mortality rate $(3.05 \%)$ compared to the other clusters.

The above type of farms achieves almost zero return in terms of invested capital, with the average gross profit amounting to EUR 27,546.46 per farm.

Cluster 2 (C2). Small farms, with mediocre feed conversion rate $(n=38)$.

The second cluster includes 38 farms characterized by low capacity per production cycle. Also, compared to the other clusters, the average number of production cycles per year (4.58) is significantly lower. In addition, they have a relatively high mortality rate (about 3\%). Most of them are located within the geographical boundaries of the Regional Unit of Ioannina.

Farms of this type achieve the highest return on invested capital, which amounts approximately to $50 \%$.

Cluster 3 (C3). Very large farms, with very bad feed conversion rate $(n=2)$.

This cluster includes 2 farms, in the Regional Units of Arta \& Ioannina. The farms are characterized as very large in size as shown by the average production capacity. Based on the worst FCR among clusters (2.24), C3 shows a liability that can be interpreted in many ways, the main one focusing on the irrational use of the supplied feed or its possible loss during feeding. This is also reflected in high production cost per $\mathrm{kg}$ of live weight.

The above farming type shows the greatest economic losses as well as the lowest average return on invested capital.

Cluster 4 (C4). Large farms, with very good feed conversion rate $(n=24)$.

This cluster, which represents $21.82 \%$ of the farms in the sample, is characterized by large-scale farms with a capacity per production cycle of approximately 50,667 broilers. It also achieves good utilization of the supplied feed while producing broilers for slaughter with the highest average live weight $(2.58 \mathrm{~kg})$.

Farms of this type show the highest return on invested capital. The investment in fixed capital is much smaller compared to the other clusters (26.00 euros/1000 broilers). In addition, this specific farming type gives the highest gross income per 4 LU (2819.56 euros). According to the above results, the farms of this type are characterized as more economically efficient compared to other clusters. 
The financial performance of each cluster for the key economic indexes is presented in Figure 2.

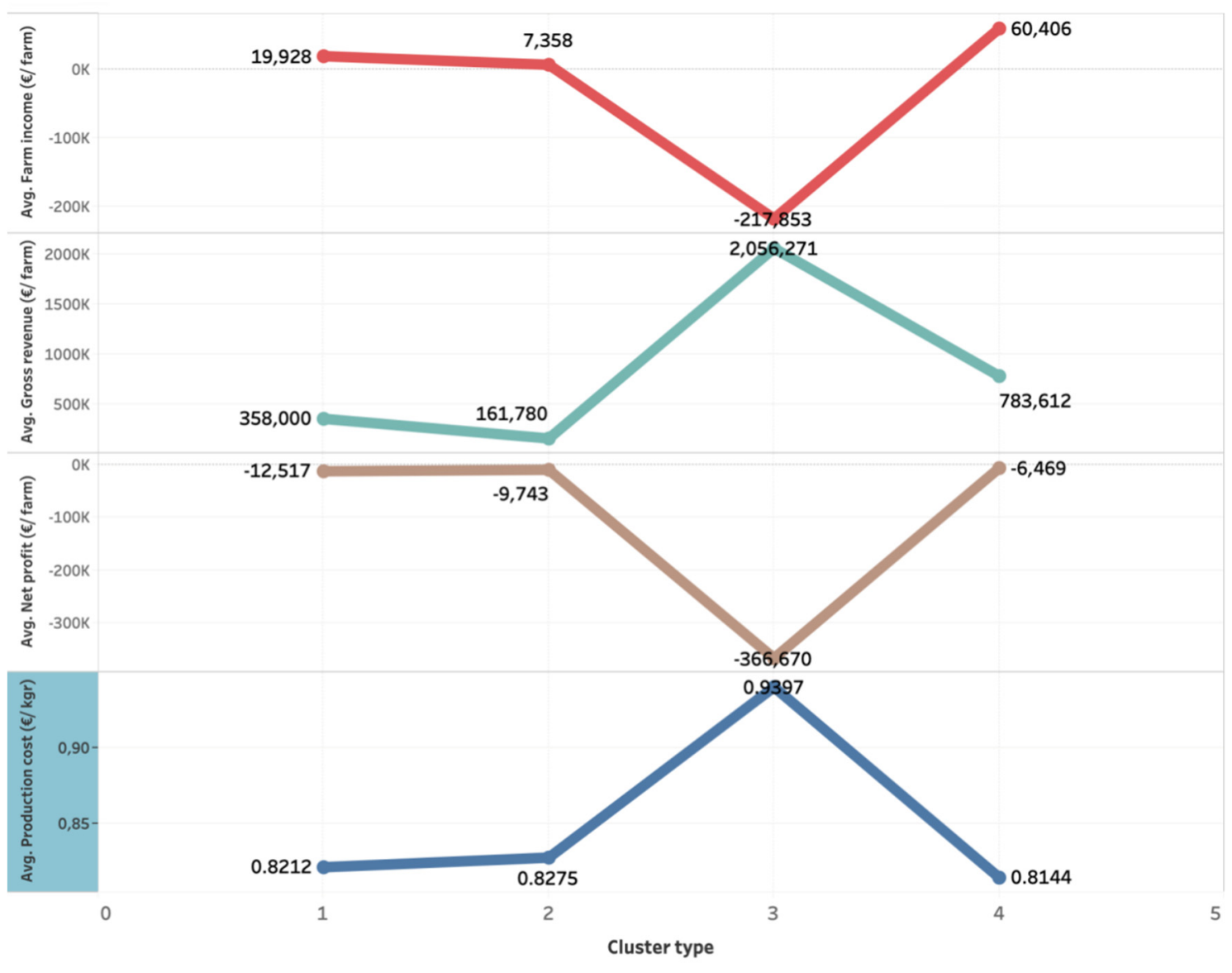

The trends of average of Farm income ( $(/$ farm), average of Gross revenue ( $€ /$ farm), average of Net profit ( $€ /$ farm) and average of Production cost ( $€ / \mathrm{kgr})$ for Cluster type.

Figure 2. Financial performance of each cluster for the key economic indexes.

\section{Discussion}

The created clusters were characterized based on the average size and the average FCR after examining a wide range of variables that influenced the classification of the farms into one of the four clusters. From the results of the hierarchical cluster analysis it is clear that large farms of the $\mathrm{C} 4$ cluster, with their very good productive performance and the lowest average production costs, determine the path that will be followed by the broiler poultry industry in the Region of Epirus. Khan and Afzal [52] reported similar findings, namely that the highest net profit benefits were observed in large-scale broiler farms followed by medium and small farms. In this study, the results concerning the profitability of the farms revealed that they are negatively affected by the mortality of the chicks, something that is also evident from the classification of the farms in our study.

Emaikwu et al. [53] reports that the increase in farm size has positively affected the expansion of poultry activity, leading poultry farmers to focus on improving production management practices that allow for the efficient use of available resources and increased productivity. Based on the above, it is expected that the 2 very large farms of the C3 category will have remarkable financial results, as they manage to have 6 annual production cycles, an extremely low mortality rate $(1.56 \%)$ and the shortest production period length (about 2 days earlier than the general average). The problem arises from the high feed consumption, which negatively affects both the production results $(F C R=2.24)$ and the economic results (production costs). Given that these are modern farms on the basis of their high fixed capital, in order to manage the existing problem, poultry farmers should 
focus on better management either by avoiding potentially extensive feed waste (e.g., poor feeder regulation) or by stricter control of inputs (quantities of feed).

The efficient, or inefficient, resource utilization of small-scale broiler farms, studied by Baba et al. [54], led them to conclude that underutilized production parameters should be increased, while the quantities of overused inputs should be more rationally managed in order to optimize their efficiency. Also, Souza et al. [13], using hierarchical cluster analysis to classify broiler farms by facility level and by checking the yield of the productivity index (PI), found that the larger farms with the largest poultry houses achieve higher performance.

Table 6 shows the average values recorded by the farms of the 4 clusters regarding the European Production Efficiency Factor (EPEF), reflecting their technical efficiency.

Table 6. Technical efficiency based on EPEF.

\begin{tabular}{cccccc}
\hline & Average & $\begin{array}{c}\mathrm{C} 1 \\
(n=46)\end{array}$ & $\begin{array}{c}\mathrm{C} 2 \\
(n=38)\end{array}$ & $\begin{array}{c}\text { C3 } \\
(n=2)\end{array}$ & $\begin{array}{c}\text { C4 } \\
(n=24)\end{array}$ \\
\hline EPEF & 295.10 & 300.73 & 284.36 & 256.44 & 305.29 \\
\hline
\end{tabular}

From the data in the above table with the European Production Efficiency Factor (EPEF), it can be concluded that primarily the large farms, which constitute the C4 cluster, and secondarily the medium-sized farms of the most populous cluster, $\mathrm{C} 1$, seem to present an excellent evaluation of their technical parameters, which are consistent with their financial results.

The explanation for this situation is based on two components: (a) the large farms of $\mathrm{C} 4$ have significantly increased the economy of scale compared to $\mathrm{C} 1$ and even more importantly with the $\mathrm{C} 2$ farm cluster, which enters the EPEF calculation equation, and (b) the equation does not include the variable "yearly placements" (annual production cycles) that affects the total production volume, even more so as the size of the farms increases.

According to Wang et al. [55], the optimum return is achieved when the EPEF reaches the highest value, which in turn is achieved when the FCR and rearing duration reach the lowest value. However, the objective in broiler production is to increase the production volume per year [56], which is directly affected by the annual production cycles.

The effect of the number of yearly placements on key economic indexes is presented in Figure 3.

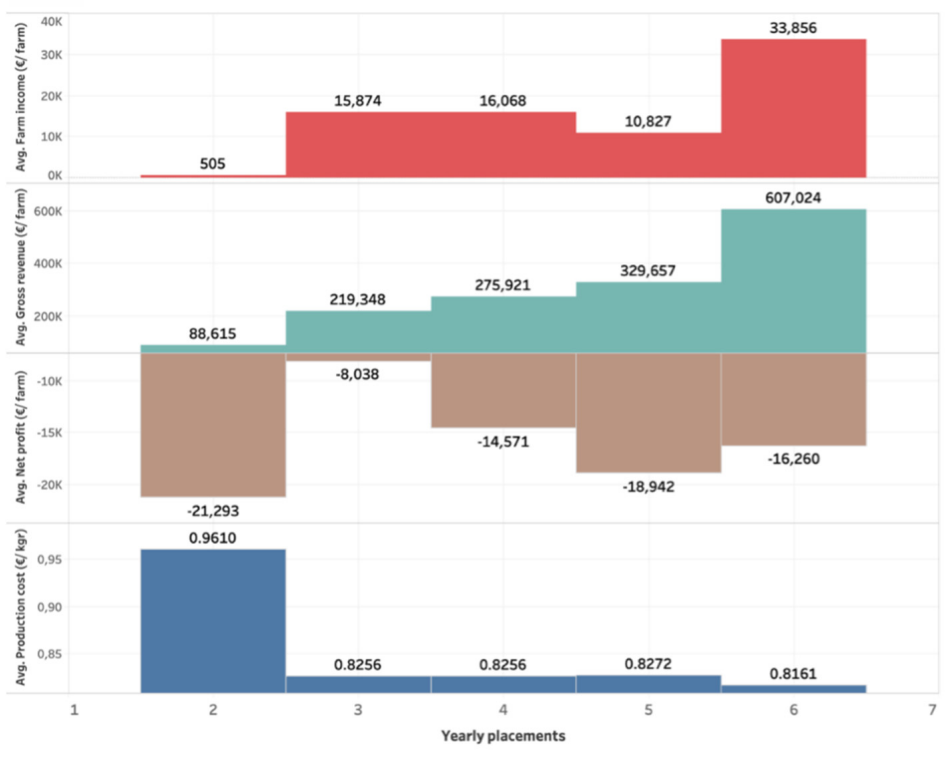

Figure 3. Effect of the number of yearly placements on key economic indexes. 
In a similar study [38], the EPEF was found to be 300.6 when the fattening days are 46 and the annual production cycles are 6.07. According to these researchers, the EPEF increases with the reduction of fattening days as the FCR improves significantly, and there is potential for more yearly placements. Another parameter that significantly affects the efficiency of broiler farms and that enters the EPEF according to Goliomytis et al. [57] is the mortality rate, which for all clusters and especially for the C4 of large farms is extremely low $(2.65 \%)$.

\section{Conclusions}

The size of the farm was a decisive parameter in the classification of farms by using hierarchical cluster analysis.

Although the C3 cluster of very large farms has been found to have good production characteristics, it cannot achieve profitability and economic sustainability if these farms do not improve their FCR. In other words, this is an example of inefficient management of modernized industrial-scale farms. Their inefficient way of operating does not allow their future financial viability and does not ensure the environmentally sustainable development of the sector.

The C2 cluster of small-scale farms is unable to follow the trend of our time to increase mass production, as these farmers do not seem willing to invest in fixed capital. Poultry farmers of this category (C2) do not have high fixed capital costs, as the facilities they use are old. However, they will have to adopt development strategies, based mainly on the modernization of current facilities, in order to improve the FCR and increase the annual number of production cycles. These farmers, who do not envision the sustainable development of their farms both from an economic and a socio-environmental point of view can be considered as conservative.

The C1 cluster of medium-sized farms seems to be on a path of modernization, but only in terms of improving their existing infrastructure, a remark confirmed by the relatively low fixed capital investment. Their size does not allow a significant increase in production volume even if their productivity parameters are intensified. In this case, too, the profile of poultry farmers needs to be investigated in order to interpret their reluctance/incapacity for further investments, so that this knowledge can be utilized by poultry companies and government agencies to create development funding tools appropriate to support the needs of the broiler poultry industry.

The already modernized large farms of the C4 cluster, in the current conditions, cannot achieve positive net profitability if their operating costs are not reduced, because the planning of production absorption by their organizations does not allow them to further increase production. This is also illustrated by two parameters in Table 4 related to the satisfactory, for the study area, status (FCR), namely the "average slaughter weight", which is $100 \mathrm{~g}$ higher than the overall average and the "average production cycle length" which is 1 day higher than the corresponding average. These observations suggest that in some production cycles it is difficult to absorb the production volume, thus affecting the efficiency (worse than expected FCR) of the C4 cluster. Finally, it seems that the C4 cluster is the model with the highest prospect of sustainable development of the industry.

The perspective of sustainable development of the sector in the Region of Epirus, an area remote from the urban centers, will contribute significantly to the social sustainability of the region, partially ensuring the employment of its population. In order to achieve sustainable development after the year 2011, a large co-operative in the area established a subsidiary whose main purpose is to utilize renewable resources for the energy requirements of their farmers and to implement an integrated waste management system that views poultry waste as an asset rather than a liability [3]. Similar actions should be adopted by the whole industry in the Region of Epirus, in order to develop into an even more environmentally friendly livestock activity, but also to reduce the production costs that will ensure the economic sustainability of broiler farming. 
Author Contributions: Conceptualization, V.D.; methodology, L.H. and I.K.; software, D.G. and I.K.; validation, I.M. and G.S.; formal analysis, D.G., L.H. and I.K.; investigation, V.D. and L.H.; resources, V.D. and L.H.; data curation, L.H., I.K. and I.M.; writing-original draft preparation, D.G. and L.H.; writing-review and editing, V.D. and G.S.; visualization, D.G., I.M. and G.S.; supervision, V.D.; project administration, V.D.; funding acquisition, V.D. and L.H. All authors have read and agreed to the published version of the manuscript.

Funding: This research was funded by the Region of Epirus in the framework of the project with C.N. 80250 and title "Pilot study to investigate development strategies of the poultry industry in the Region of Epirus".

Data Availability Statement: All the relevant data are available in the paper.

Acknowledgments: We sincerely thank the poultry farmers who participated in the survey and answered the questions asked to them through personal interviews.

Conflicts of Interest: The authors declare no conflict of interest.

\section{References}

1. Elstat, Hellenic Statistical Authority. 2018. Available online: www.statistics.gr (accessed on 26 March 2019).

2. Camargo-Barros, G.S.; Zen, S.D.; Piedade-Bacchi, M.R.; Galvão de Miranda, S.H.; Narrod, C.; Tiongco, M. Policy, technical, and environmental determinants and implications of the scaling-up of swine, broiler, layer and milk production in Brazil. In Annex V, Final Report of IFPRI-FAO Livestock Industrialization Project: Phase II; International Food Policy Research Institute: Washington, DC, USA, 2003.

3. Iliopoulos, C.; Theodorakopoulou, I. Measuring and Communicating the True Value of Membership: The Case of the Pindos Poultry Co-operative. In Sustainable Co-operative Enterprise: Case Studies of Organisational Resilience in the Co-operative Business Model; Chapter 17; Mazzarol, T., Reboud, S., Limnios, E.M., Eds.; Edward Elgar Publishing: Cheltenham, UK, 2014; pp. 223-239.

4. Burgos, S.; Hong Hanh, P.T.; Roland-Holst, D.; Burgos, S.A. Characterization of Poultry Production Systems in Vietnam. Int. J. Poult. Sci. 2007, 6, 709-712. [CrossRef]

5. Keramidou, I.; Mimis, A.; Pappa, E. Performance evaluation of the poultry sector in Greece. J. Food Agric. Environ. 2011, 9, 431-437.

6. Koutoulis, K. Present and future of poultry industry in Greece. In Proceedings of the 12th Pan-Hellenic Veterinary Congress, Athens, Greece, 5-8 April 2012.

7. Eurostat Trade Statistics. 2018. Available online: https://ec.europa.eu/eurostat/web/main/data/database (accessed on 26 March 2019).

8. Eurostat. Sustainable Development in the European Union; Key Messages; Office for Official Publications of the European Communities: Luxembourg, 2015. Available online: https:/ / ec.europa.eu/eurostat/documents/3217494/6975281/KS-GT-15-001-EN-N. pdf (accessed on 26 March 2019).

9. Dormady, N.; Roa-Henriquez, A.; Rose, A. The Resilience of the Firm. A Production Theory Approach. Int. J. Prod. Econ. 2017, 208, 446-460. [CrossRef]

10. Unay-Gailhard, I.; Balmann, A.; Appel, F. Dimensions of SURE-Farm Farm Typology for Farm Resilience Assessments. In Working Paper (727520); Leibniz Institute of Agricultural Development in Transition Economies (IAMO): Madrid, Spain, 2018.

11. Andersen, E. Regional Typologies of Farming Systems Contexts, SEAMLESS Report No.53, SEAMLESS 2010 Integrated Project, EU 6th Framework Programme, Contract no. 010036-2. Available online: http://www.seamless-ip.org/Reports/Report_53_PD4 .4.3.pdf (accessed on 26 March 2019).

12. Kruskal, J. The Relationship between Multidimensional Scaling and Clustering. In Classification and Clustering; Van Ryzin, J., Ed.; Academic Press Inc.: New York, NY, USA, 1977; pp. 17-45.

13. Souza, F.; Milani, A.; Furlan, R.; Nogueira, W.; Fernandez Alarcon, M.F.; Almeida, E. Cluster Analysis to Study the Typology and Productivity in Broiler Facilities. In Proceedings of the International Conference of Agricultural Engineering (CIGR-Ageng2012), Valencia, Spain, 6-12 July 2012.

14. Worapol, A.; Manakant, I.; Jaroon, W.; Thanapol, N.; Surangkanang, C.; Prayat, S.; Komvut, T.; Neti, J.; Khlahan, S.; Tawinwaang, T. Poultry Production Clusters (PPCs) after AI Outbreaks in Thailand: Past, Present and Future Direction. Int. J. Poult. Sci. 2012, $11,541-550$.

15. Thevenot, A.; Aubin, J.; Tillard, E.; Vayssieres, J. Accounting for farm diversity in Life Cycle Assessment studies-The case of poultry production in a tropical island. J. Clean. Prod. 2013, 57, 280-292. [CrossRef]

16. Rymuza, K.; Grużewska, A.; Biesieda-Drzazga, B. Multidimensional analyses in studies on broiler chicken production results. Europ. Poult. Sci. 2014, 78, 22.

17. Gocsik, E.; Brooshooft, S.D.; De Jong, I.C.; Saatkamp, H.W. Cost efficiency of animal welfare in broiler production systems: A pilot study using the Welfare Quality ${ }^{\circledR}$ assessment protocol. Agric. Syst. 2016, 146, 55-69. [CrossRef]

18. Roskam, J.L.; Oude Lansink, A.G.J.M.; Saatkamp, H.W. The relation between technical farm performance and antimicrobial use of broiler farms. Poult. Sci. 2020, 99, 1349-1356. 
19. Bastianoni, S.; Boggia, A.; Castellini, C.; Di Stefano, C.; Niccolucci, V.; Novelli, E.; Paolotti, L.; Pizzigallo, A. Measuring Environmental Sustainability of Intensive Poultry-Rearing System. In Genetic Engineering, Biofertilisation, Soil Quality and Organic Farming; Lichtfouse, E., Ed.; Springer: Dordrecht, The Netherlands, 2010; Volume 4, pp. 277-309.

20. Castellini, C.; Bastianoni, S.; Granai, C.; Dal Bosco, A.; Brunetti, M. Sustainability of poultry production using the emergy approach: Comparison of conventional and organic rearing systems. Agric. Ecosyst. Environ. 2006, 114, 343-350. [CrossRef]

21. Vaarst, M.; Steenfeldt, S.; Horsted, K. Sustainable development perspectives of poultry production. Worlds Poult. Sci. J. 2015, 71, 609-620. [CrossRef]

22. Chotteau, P.; Beaumond, N.; Deblitz, C.; Hoste, R.; Magdelaine, P.; Mottet, A.; De Roest, K.; Roguet, C.; Sarzeaud, P.; Topliff, M.; et al. The Impact of Increased Operating Costs on Meat Livestock in the EU. Study for the European Parliament. Paris. Institut de l' Elevage. 2009. Available online: http:/ / www.europarl.europa.eu/RegData/etudes/etudes/join/2009/419109/ IPOLAGRI_ET(2009)419109_EN.pdf (accessed on 18 March 2019).

23. Van Horne, P.L.M. Competitiveness of the EU poultry Meat Sector, Base Year 2017. In Wageningen Economic Research Report 2018-116; Wageningen University \& Research: Wageningen, The Netherlands, December 2018. [CrossRef]

24. Leinonen, I.; Kyriazakis, I. How can we improve the environmental sustainability of poultry production? Proc. Nutr. Soc. 2016, 75, 265-273. [CrossRef]

25. Gerber, P.; Opio, C.; Steinfeld, H. Poultry Production and the Environment-A Review; Animal Production and Health Division, FAO: Rome, Italy, 2007; Available online: http://www.fao.org/ag/againfo/home/events/bangkok2007/docs/part2/2_2.pdf (accessed on 11 March 2019).

26. Sell-Kubiak, E.; Wimmers, K.; Reyer, H.; Szwaczkowski, T. Genetic aspects of feed efficiency and reduction of environmental footprint in broilers: A review. J. Appl. Genet. 2017, 58, 487-498. [CrossRef]

27. Hume, D.A.; Whitelaw, C.B.A.; Archibald, A.L. The future of animal production: Improving productivity and sustainability. J. Agric. Sci. 2011, 149, 9-16. [CrossRef]

28. De Verdal, H.; Mignon-Grasteau, S.; Bastianelli, D.; Même, N.; Le Bihan-Duval, E.; Narcy, A. Reducing the environmental impact of poultry breeding by genetic selection. J. Anim. Sci. 2013, 91, 613-622. [CrossRef] [PubMed]

29. Kawsar, M.H.; Chowdhury, S.D.; Raha, S.K.; Hossain, M.M. An analysis of factors affecting the profitability of small-scale broiler farming in Bangladesh. Worlds Poult. Sci. J. 2013, 69, 676-686. [CrossRef]

30. Martins, J.M.S.; Carvalho, C.M.C.; Litz, F.H.; Silveira, M.M.; Moraes, C.A.; Silva, M.C.A.; Fagundes, N.S.; Fernandes, E.A. Productive and Economic Performance of Broiler Chickens Subjected to Different Nutritional Plans. Braz. J. Poult. Sci. 2016, 18, 209-216. [CrossRef]

31. Kamran, Z.; Sarwar, M.; Nisa, M.; Nadeem, M.A.; Mahmood, S.; Babar, M.E.; Ahmed, S. Effect of low-protein diets having constant energy-to-protein ratio on performance and carcass characteristics of broiler chickens from one to thirty-five days of age. Poult. Sci. 2008, 87, 468-474. [CrossRef] [PubMed]

32. Moosavi, M.; Eslami, M.; Chaji, M.; Boujarpour, M. Economic value of diets with different levels of energy and protein with constant ratio on broiler chickens. J. Anim. Vet. Adv. 2011, 10, 709-711. [CrossRef]

33. Willems, O.W.; Miller, S.P.; Wood, B.J. Assessment of residual body weight gain and residual intake and body weight gain as feed efficiency traits in the Turkey (Meleagris gallopavo). Genet. Sel. Evol. 2013, 45, 26-65. [CrossRef]

34. Lourenço, I.C.; Branco, M.C. Determinants of corporate sustainability performance in emerging markets: The Brazilian case. J. Clean. Prod. 2013, 57, 134-141. [CrossRef]

35. Reyer, H.; Hawken, R.; Murani, E.; Ponsuksili, S.; Wimmers, K. The genetics of feed conversion efficiency traits in a commercial broiler line. Sci. Rep. 2015, 5, 16387. [CrossRef]

36. Marcu, A.; Vacaru-Opris, I.; Gabi, D.; Liliana, P.C.; Marcu, A.; Marioara, N.; Ioan, P.; Dorel, D.; Bartolomeu, K.; Cosmin, M. The Influence of Genetics on Economic Efficiency of Broiler Chickens Growth. Anim. Sci. Biotech. 2013, 46, 339-346.

37. Tolimir, N.; Milošević, N.; Ceranić, C.; Škrbić, Z.; Maslovarić, M. The effect of feeding programmes on broiler performance and production efficiency. In Proceedings of the International Symposium on Animal Science, Belgrade-Zemun, Serbia, 23-25 September 2014; Available online: http:/ /agris.fao.org/agris-search/search.do?recordID=RS2017000916 (accessed on 11 March 2019).

38. Szőllősi, L.; Szúcs, I.; Nábrádi, A. Economic issues of broiler production length. Econ. Agric. 2014, 61, 633-646. [CrossRef]

39. Tandoğan, M.; Cicek, H. Technical Performance and Cost Analysis of Broiler Production in Turkey. Braz. J. Poult. Sci. 2016, 18, 169-174. [CrossRef]

40. Abdel-Latif, M.A.; El-Far, A.H.; Elbestawy, A.R.; Ghanem, R.; Mousa, S.A.; Abd El-Hamid, H.S. Exogenous dietary lysozyme improves the growth performance and gut microbiota in broiler chickens targeting the antioxidant and non-specific immunity mRNA expression. PLoS ONE 2017, 12, e0185153.

41. El-Menawey, M.; Attallah, A.; Abdel-Aziz, Y.; Yossif, M.; Gharib, H. Characterization and constrains of semi-intensive broiler production system in rural sector of Al-Sharkia and El-Qalioba governorates, Egypt. Egypt. Poult. Sci. J. 2019, 39, 311-326. [CrossRef]

42. Food and Agriculture Organization of the United Nations. Guidelines for Development of a Classification System Related to Farm Typology. 2018. Available online: http:/ / www.fao.org/3/ca6391en/ca6391en.pdf (accessed on 26 March 2019).

43. Neyman, J. On the two different aspects of the representative methods. J. R. Stat. Soc. 1934, 97, 558-606. [CrossRef]

44. Cochran, W.G. Sampling Techniques; John Wiley \& Sons: New Delhi, India, 1977. 
45. Brannen, J. Mixing Methods: The Entry of Qualitative and Quantitative Approaches into the Research Process. Int. J. Soc. Res. Methodol. 2005, 8, 173-184. [CrossRef]

46. Daoutopoulos, G.; Kazakopoulos, L.; Koussi, M. Agricultural Sociology; Zygos Publications: Thessaloniki, Greece, 2005.

47. Siardos, G. Social Research Methodology; Ziti Publications: Thessaloniki, Greece, 2009.

48. Iraizoz, B.; Gorton, M.; Davidova, S. Segmenting farms for analysing agricultural trajectories: A case study of the Navarra region in Spain. Agric. Syst. 2007, 93, 143-169. [CrossRef]

49. Norušis, M.J. IBM SPSS Statistics 19. In Statistical Procedures Companion; Prentice Hall: Upper Saddle River, NJ, USA, 2011.

50. Hair, J.F.; Black, W.C.; Babin, B.J.; Anderson, R.E.; Tatham, L.R. Multivariate Data Analysis, 6th ed.; Pearson Prentice Hall: Upper Saddle River, NJ, USA, 2007.

51. Everitt, B.S.; Landau, S.; Leese, M.; Stahl, D. Cluster Analysis; John Wiley \& Sons: Chichester, UK, 2011.

52. Khan., M.; Afzal, M. Profitability analysis of different farm size of broiler poultry in district dir (lower). Sarhad J. Agric. 2018, 34, 389-394. [CrossRef]

53. Emaikwu, K.K.; Chikwendu, D.O.; Sania, S. Determinants of flock size in broiler production in Kaduna State of Nigeria. J. Agric. Ext. Rural Dev. 2011, 3, 202-211.

54. Baba, M.D.; Attahiru, M.; Sanda, A.Y. Estimating Resource Productivity and Efficiency of Smallholder Broiler Production in Bida Metropolis, Niger State, Nigeria. N. Y. Sci. J. 2016, 9, 24-28.

55. Wang, B.Y.; Chien, L.H.; Roan, S.W. POMA-BROILER: A Computer Simulation Model to Evaluate the Optimal Market Age of Broilers. J. Anim. Vet. Adv. 2012, 11, 2493-2502.

56. Samarakoon, S.M.R.; Samarasinghe, K. Strategies to improve the cost effectiveness of broiler production. Trop. Agric. Res. 2012, 23, 338-346. [CrossRef]

57. Goliomytis, M.; Panopoulou, E.; Rogdakis, E. Growth Curves for Body Weight and Major Component Parts, Feed Consumption, and Mortality of Male Broiler Chickens Raised to Maturity. Poult. Sci. 2003, 82, 1061-1068. [CrossRef] [PubMed] 